January 2014

\title{
Education policy and social justice: Exploring possibilities within education policy context of Pakistan
}

Sajid Ali

AgaKhan University, sajid.ali@aku.edu

Follow this and additional works at: http://ecommons.aku.edu/pakistan_ied_pdck

Part of the Educational Assessment, Evaluation, and Research Commons, Higher Education Administration Commons, Higher Education and Teaching Commons, Other Education Commons, Other Educational Administration and Supervision Commons, Other Teacher Education and Professional Development Commons, and the Scholarship of Teaching and Learning Commons

\section{Recommended Citation}

Ali, S. (2014). Education policy and social justice : Exploring possibilities within education policy context of Pakistan. Pakistan Perspectives, 19(1), 77-86. 


\title{
Education Policy and Social Justice: Exploring Possibilities within Education Policy Context of Pakistan*
}

\author{
Sajid Ali*
}

\begin{abstract}
One of the major purposes of education policy is to ensure social justice in a society. The social justice needs to be thought of not only in conventional sense of 'distributional' justice, but also in the sense of 'relational' justice. Looking from this perspective the policies in Pakistan have historically focused only on distributional justice, albeit with dismal progress on this front. However, they have completely ignored the attainment of 'relational' justice as a policy objective. As a result power differentials not only exist but worsened through educational policies such as undermining of public schooling while encouraging privatization of education and creating and sustaining 'educational apartheid'. Over concerns with ideology and language issues through education policy has undermined the focus on social justice even in current policy. Global educational targets have further aggravated this issue by engaging governments in attaining universal targets that hide the social justice concerns in a holistic way. In order to make any difference in the current situation, the focus of attention should not only be limited to critiquing the policy per se, rather an attempt needs to be made in challenging the relations of power at educational sites: schools, colleges and universities. Why can not we think of creating educational institutions (school, colleges, universities and teacher training facilities) which challenge the status quo and develop human resource of tomorrow that challenges the existing power structures of our society and help attain both distributional as well as relational social justice? In terms of policy we have to think of three simultaneous actions: act, educate and advocate.
\end{abstract}

\section{Introduction}

Let me start by sharing a personal narrative as a window to approach questions of education policy and social justice in Pakistan. I grew up in a middle class locality in Karachi (biggest city of Pakistan, approximate

An earlier version of the paper was presented at the conference on Education and Social Justice, Islamabad, 29 March 2010, organised by Strengthening Participatory Organisations (SPO) Pakistan.

** Dr. Sajid Ali, Assistant Professor, Aga Khan University, Institute for Educational Development, Karachi. 
population 18 million) and like many other children in the neighbourhood went to a nearby government school. It was quite reputable in those times (around 1980s and early 1990s); the teachers as I recall them were passionate about their teaching and owned the school. We too were supposedly 'good students' and used to receive extra support from teachers in order to raise the profile of the school in state mandated school leaving examination. Fast forward 10 years (around 2001), I visited my school which presented a very different look, I could sense the misery of school's material structure, its teachers and students. The students' profile was substantially changed and I could see mostly working class children in the school. Fast forward 10 more years (around 2011) and I heard that that government school is no longer there. Shockingly when I tracked further, it was revealed that the premises in which my school used to run, now has many buildings erected each one named as a different school. So within one premises there are 4-5 schools running each having different name and my school has also moved to one of those buildings and is not easily distinguishable. On a micro level this is the story of one government school but based on my personal experience of being in the education sector for more than a decade and visiting number of schools across Pakistan, the demise of government schools seems a prevalent phenomenon.

Many lessons can be drawn from this story but the lesson that I want to focus is the one relevant to the purpose of this article i.e. education policy and social justice. From this perspective, I see a loss of educational opportunity for children of quality and affordable education through public source. The vacuum created by the poor public education system is being filled by various sorts of private provision. The education policy that supports growth of private provision and discourages (or fails to improve) public provision is certainly at odds with the principles of social justice. These issues and the possible remedial actions are the central concern of this article.

In this paper I would first like to say something about the conceptions of education and social justice. I will then move to see current education policy of Pakistan from a social justice lens. The final section will talk about possibilities for attaining social justice through education (policy).

\section{Education policy}

I would like to outline below, in very crude and in a generalized sense the misunderstanding that many people, including educationists, have about education policy: 
First, that there is a clear distinction between policy making and policy implementation.

Second, that we have to put great efforts in bringing out a brilliant and flawless policy and if that is ensured the implementation would follow automatically and unproblematically.

Third, that education policies are painstakingly made and the problem generally lies at the implementation level. In the preface of the current education policy of Pakistan (November 2009) the education minister says, 'Pakistan has produced a number of educational policies in the past and all have been quality documents in their own right. The failure has always been in the commitment and implementation'.

Fourth, that policy is always written and/or spoken mainly in the form of a policy document, report or public statement.

Fifth, that state has the sole authority to determine national policy of any country.

Stephen Ball $^{2}$ clarifies these policy fallacies and asserts that policy is not only a product but also the process that leads to the production of policy and follow from it. It gets shaped and reshaped within three contexts, which are: context of text production, context of influence and context of practice. In each of these contexts the policy issues and their purported solutions get transformed depending on the actors, contexts and political exigencies. Thus policy is not something fixed and therefore implementation is not clearly separated from production because in different contexts policy is re-interpreted before being acted upon.

$\mathrm{Ozga}^{3}$ further adds that a policy text is any 'vehicle or medium for carrying and transmitting a policy message'. Policy is generally employed to make changes in the practice or standardizing the practices for delivering public good. Thus the distinction between policy making and implementation appears to be a false one and does not reflect the empirical realities, a phenomena initially popularized by American policy scientists Charles E. Lindblom. ${ }^{4}$ Against the then American mainstream policy thinkers, Lindblom argued that policy making is a 'muddling through' process and involves such political processes as

1 National Education Policy 2009 (Islamabad: Ministry of Education, Government of Pakistan), p.vii.

2 S.J. Ball, Education policy and social class: The selected Works of Stephen J. Ball (London: Routledge, 2006).

3 J. Ozga, Policy Research in Educational Settings Contested Terrain (Buckingham: Open University Press, 2000), p.33.

4 C.E. Lindblom, 'The Science of "muddling through"', Public Administration Review, 19:2 (1959), pp.79-88. 
bargaining, negotiating and compromising. This challenges the views of rationalist policy scholars like Lasswell ${ }^{5}$ and Nagel, ${ }^{6}$ who take a positivist stance towards policy analysis and insist that policy development is an objective and scientific process. It is interesting to note that in Pakistan the debate on policy making and implementation is still at a very nascent stage, whereby scholars tend to highlight and pose serious doubts over whether policy actually reaches at the level of practice. The policy scholarship in Pakistan still needs to explore the areas of interpretation, reinterpretation or reformulation of education policy.

Policies are also not always written or spoken. What is not said and not written is equally important and in some instances more important than what is written or spoken. Michael Apple ${ }^{8}$ highlights that policy is a lot about politics, education policy is an act of education politics and in politics not only action but in-actions are meaningful. A very famous definition of policy describes policy as the authoritative

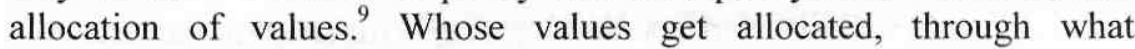
processes and with what consequences are political questions from this perspective, which are often glossed over in the debates of policy not only in Pakistan but across the globe. Policy is not a neutral process of objectively determining the goals and then charting out the best course of action to attain them. ${ }^{10}$ If we take a political view of policy then education policy holds serious consequences for social justice.

\section{Social justice}

Let us start by a two-part working definition of social justice offered by Morwenna Griffiths ${ }^{11}$ as follows:

5 H.D. Lasswell, 'The Policy Orientation', in D. Lerner \& H. D. Lasswell (eds.), The Policy Sciences: Recent Developments in Scope and Methods (Stanford, CA: Stanford University Press, 1951), pp.3-15.

6 S.S. Nagel, 'Trends in Policy Analysis', in Public Policy: The Essential Readings, Prentice Hall, 1955, pp.181-85.

7 S. Ali, 'Deficient Policy Communication Deficient Outcomes - Capacity Building Policy under Education Reforms in Sindh, Pakistan', Bulletin of Education and Research, 33:1 (2011), pp.1-19.

M.W. Apple, 'Can Schooling Contribute to a More Just Society?' Education, Citizenship and Social Justice, 3:3 (2008), pp.239-61.

9 B. Lingard, 'Some General Observations about Education Policy in the Context of Globalization', in F. Rizvi \& B. Lingard (eds.), Globalizing Education Policy (London: Routledge, 2009).

11 M. Griffiths, Educational Research for Social Justice: Getting Off the Fence (Buckingham: Open University Press, 1998), p.89. 
1. It is the good for the common interest, where that is taken to include the good of each and also the good of all, in an acknowledgement that one depends on the other.

2. The good depends on there being a right distribution of benefits and responsibilities.

The definition alludes to the fact that the core concern of social justice is to ensure wellbeing of the individual as well as collectivity, where both are inter-dependant. Justice in a society can be achieved through equitable distribution of benefits and responsibilities. In this sense it is expected from the citizens to perform their expected functions for the common good and to expect a fair treatment by the authority. Hence, social justice is achieved through the responsive behaviour of citizens, fair distribution of benefits by the authority and achievement of common good for all by all.

Sharon Gewirtz ${ }^{12}$ writing in the special issue of Journal of Education Policy presents a very useful way of conceptualizing social justice. She argues that much of the focus on social justice concerns has remained at the level of 'distributional' justice, while the concerns for 'relational' justice are generally ignored or silenced. By distributional justice she means attempts to ensure equal distribution of opportunities, goods and resources for each member of the society. Relational justice focuses not only on individual rather on groups as well and their relationships with broad power structures and with other groups and individuals from macro to micro levels. The nature of these relationships makes certain groups privileged over others. Though the two are interconnected and intertwined but ignoring the relational aspect does injustice to the very notion of social justice. While the distribution of opportunities and goods is important the relational structures within which this distribution takes place is equally, rather more important.

In educational setting, the distributional justice would result in concern of, for example: ensuring access to education, ensuring gender balance, equal curriculum choices and opportunities for further growth. The 'relational' justice would raise concerns about broad power structures that promote educational inequality, which in fact hinder even the attainment of distributional concerns. It raises the concerns about for example the elite and non-elite education system, the structure that ensures continuation of existing social disparities or the determined low quality educational trajectory for working class children.

12 S. Gewirtz, 'Conceptualizing Social Justice in Education: Mapping the Territory', Journal of Education Policy, 13:4 (1998), pp.469-84. 
With some general understanding of both education policy and social justice, I would now like to look at the current education policy of Pakistan National Education Policy 2009 (NEP 2009) from a social justice perspective. I would focus more on the relational aspects of social justice, though it is fair to acknowledge that the two (distributional and relational) are not mutually exclusive.

\section{The current education policy of Pakistan from a social justice lens}

Kazim Bacchus ${ }^{13}$ asserts that education had a promising beginning (at least intentionally) in most postcolonial countries. In fact education was considered to not only develop the nation but also to create harmony among different groups and ultimately ensure social justice. ${ }^{14}$ This initial optimism could not result in a desired outcome, and education rather than becoming an equalizer actually became an instrument of sustaining social stratification, with the only difference of replacing colonial power with local elites. ${ }^{15}$ In considering the relational social justice, this seems to be the case of Pakistan too. Rahman ${ }^{16}$ asserts that during the colonial period in India two kinds of elite schools were created: i) Chiefs' Colleges; and ii) European or English schools. The first ones were for the hereditary aristocracy and the second ones were for the then newly emerging professional classes. The division between elite schools and schools for commoners continued even after the creation of Pakistan in 1947. Infact, 'as the military and the higher bureaucracy both came from this elite, these schools multiplied in Pakistan as the professional middleclass started expanding in the sixties'. ${ }^{17}$ At the moment Pakistan has different categories of schools matching social classes. Thus elite private schools cater for elites, private schools for middle class, low cost private schools and public schools for lower class and madrassas (religious schools) for the poorest.

Reflecting on the story shared in the beginning, it is worth pondering whether education in Pakistan has increased or decreased the opportunities for poorer segments of society over the years. The children

13 M.K. Bacchus, 'Education for Development and Social Justice in the Third World', in T.J. Scrase (ed.), Social justice and Third World Education (New York: Garland Publishing, 1997).

14 M. Carnoy, \& J. Samoff, Education and Social Transition in the Third World (Princeton: Princeton University Press, 1990).

M.K. Bacchus, op.cit.

16 T. Rahman, Denizens of Alien Worlds: A Study of Education, Inequality and Polarization in Pakistan (Karachi: Oxford University Press, 2009).

Ibid., p.48. 
of today have to go to private schools to get the kind of education that we were able to get from public schools for almost free. The poor assessment results of public schools from official sources attest that the quality of learning has declined there. Students in the province of Sindh scored only $44.7 \%$ in mathematics for grade 4 assessments in the year 2009. ${ }^{18}$

Let us now look at what the current education policy has to say about the social justice concerns. The policy states,

The educational system in Pakistan is accused of strengthening the existing inequitable social structure as very few people from the public sector educational institutions have the potential to move up the ladder of social mobility. If immediate attention is not paid to reducing social exclusion and moving towards inclusive development in Pakistan, the country can face unprecedented social upheavals. $^{19}$

The excerpt indicate that the government realises that there are accusations made over its performance over creating and continuing with an inequitable education system, which restrict the mobility of disadvantaged. The consequences of such injustices would be stark. Having pointed out the importance of social justice and accepting the poor performance of the government in achieving this, the policy also shows that there have remained a 'commitment gap' towards education development. One indication of this lack of political commitment is the allocation of meagre budgetary resources for education, which have stayed roughly around $2 \%$ of GDP or just over it. However, a document from the Ministry of Education reveals that actual expenditure is usually lower than the allocation. It was $1.9 \%$ in 2009 . Due to this commitment tragedy the educational profile of Pakistan reflects the worst performance within the South Asian region. ${ }^{20}$

This lack of political commitment if seen in relation to the earlier referred writing of Kazim Bacchus ${ }^{21}$ suggests that the interest of government does not seem to be in ensuring equal educational opportunities for all. He argued that after the departure of colonizers the elites in those countries have captured the power structures of the country. Once occupying the power the elites used the state machinery to increase and sustain stratification structures to their own advantage. This

\footnotetext{
18 Provincial Education Assessment Centre, 2010.

19 National Education Policy 2009, op.cit., pp.5-6.

20 Ibid.

21 K. Bacchus, op.cit.
} 
is what Gewirtz ${ }^{22}$ would consider an outcome of our overlooking of issues of 'relational social justice'. Thus even in the current policy the government seems to worry a lot about the concerns of 'distributional justice' by putting efforts to increase enrolment, however, not taking any serious measure to break divisive education structure beyond rhetoric.

The policy further comments on the parallel education system and observes that it enhances social stratification and goes against the social justice principles:

Existence of insulated parallel systems of public and private education in Pakistan remains a cause for concern as it creates inequitable social divides. First, a small but important component of the private sector caters to the elite and offers high quality that only the rich can afford. Its longterm socioeconomic impact is divisive for the society, not the least in the relative neglect of improvements in the public sector. $^{23}$

Despite these concerns and their acceptance most policy recommendations in NEP 2009 are geared to ensure distributional justice through widening the access, improving the quality of curriculum and teaching, improving governance and assessment of students' achievement. A question may be asked: would the proposed policy recommendations by NEP 2009 ensure social justice? The answer is most likely to be in negative in the sense of Gewirtz's relational social justice. At maximum, the policy could only ensure distributional justice even if it achieves hundred per cent implementation as envisaged. In fact while NEP 2009 notes serious issues due to public private divide in education, it further encourages privatisation of education through such initiatives as public private partnerships and adopt a school programme (private adoption of public school).

\section{Can anything be done about it?}

In order to make any difference in the current situation, the focus of attention should not only be fixated at critiquing the policy per se, rather an attempt need to be made in exploring the possibilities of challenging the relations of power at the sites of education i.e. schools, colleges and universities. After all, it is understood that policy is not only what is said but also what is practiced. Bacchus ${ }^{24}$ points that in postcolonial countries (mostly third world) the small elite group has taken control of the power 
and even state machinery is being used to consolidate and maintain that hegemony. Education thus is being geared to legitimise the existence of current stratification and power structure rather than challenging it. Thus the role of critical teachers and teaching in schools and educational institutions is of critical importance. This is messy and hard proposition, yet it seems a likely possibility. We assume that there is easy sailing for educators in developed world, but the fact remains that the same concerns of social justice are very much alive there and the same call for critical schools and pedagogy is being made. ${ }^{25}$ The schools in USA also struggle for overcoming social inequities. James Beane and Michael Apple have produced a book Democratic schools: lessons from the chalk face presenting stories of such schools and educators who are struggling and also succeeding in challenging the status quo and bringing critical aspects into the school, their teaching and their kids' thinking. ${ }^{26}$ There are lessons and inspirations in it for us too.

From policy point I propose that we have to engage in a three pronged strategy to connect policy with practice but also to bring about change in the way our education is being governed; these are: Act, Educate and Advocate. Act, refers to a more 'action oriented' strategy and contains the element of doing at the level of practice e.g. creating schools or educational facilities to demonstrate the possibilities of doing things differently. In a way it is a bottom up approach to policy. Educate, refers to a more 'academic oriented' strategy and calls for doing and disseminating educational research with a social justice concern. ${ }^{27}$ Advocate, is a more 'civil society oriented' strategy and involves such efforts like running campaigns, lobbying and media presentations.

I understand that these are very broad and vague initial thought and I present them not as a concrete line of action rather as proposal for consideration for our scholars, educationists, activists, teachers and parents.

Why can't we think of creating educational institutions (school, colleges, universities and teácher training facilities) which challenge the status quo and develop human resource of tomorrow that can challenge the existing power structures of our society and help attain both distributional as well as relational social justice?

Why can't we engage in educational research that raises critical questions and disseminate it creatively at different forums that are

M.W. Apple, op.cit.

J.A. Beane \& M.W. Apple (eds.), Democratic Schools: Lessons from the Chalk Face (Buckingham: Open University Press, 1999). 
attended not only by academics but also by policy makers, activists, practitioners, teachers and parents?

Why can't we develop campaigns that not only seek to attain global agendas of Education For All (EFA) or Millennium Development Goals (MDGs) but also highlight some critical agendas of national importance?

I know these are tough propositions and hard to pursue and still nascent thoughts but I propose that we debate these issues and explore the possibilities for improving and introduce better alternatives. 